\title{
In vitro investigation of anticancer, antihypertensive, antidiabetic, and antioxidant activities of camel milk fermented with camel milk probiotic: A comparative study with fermented bovine milk
}

\author{
Mutamed Ayyash, ${ }^{* 1}$ Ayesha S. Al-Dhaheri,† Suheir Al Mahadin, ${ }^{*}$ Jaleel Kizhakkayil, $\dagger$ and Aisha Abushelaibi* \\ ${ }^{*}$ Food Science Department, and \\ †Nutrition and Health Science Department, College of Food and Agriculture, United Arab Emirates University, PO Box 1555, Al Ain, \\ United Arab Emirates
}

\begin{abstract}
This study aimed to investigate in vitro anticancer activity by antiproliferative activity, antihypertensive activity by angiotensin-converting enzyme inhibition, antidiabetic activity by $\alpha$-amylase and $\alpha$-glucosidase inhibitions, and antioxidant activities of camel milk fermented with camel milk probiotic compared with fermented bovine milk. The camel milk probiotic strain Lactococcus lactis KX881782 (Lc.K782) and control Lactobacillus acidophilus DSM9126 (La.DSM) were used to prepare fermented camel and bovine milks separately. The proteolytic activities of water-soluble extract (WSE) in all fermented camel milk were higher than those in fermented bovine milk. The $\alpha$-glucosidase inhibitions in both milk types fermented by Lc.K782 ranged from 30 to $40 \%$. Camel milk fermented by Lc.K782 had the highest antioxidant activity by 2,2'-azino-bis(3-ethylbenzo-thiazoline-6-sulphonic

acid). The highest angiotensin-converting enzyme inhibition of WSE in camel milk fermented by Lc.K782 was $>80 \%$. The proliferations of Caco-2, MCF-7, and HELA cells were more inhibited when treated with WSE of fermented camel milk extracts.
\end{abstract}

Key words: camel milk, antihypertensive, probiotic, antidiabetic, anticancer

\section{INTRODUCTION}

Camels are found in Africa and Asia and are kept mostly by nomads and tribes living in desert regions. Australia has half a million wild camels, especially in the Northern Territory. Worldwide, there are 2 wellknown species of camels: 1-humped Arabian camels or dromedaries (Camelus dromedarius; the camels of the plains) and 2-humped Bactrian camels (Camelus bac-

Received June 27, 2017.

Accepted October 11, 2017

${ }^{1}$ Corresponding author: mutamed.ayyash@uaeu.ac.ae trianus; the camels of the mountains; Fukuda, 2013). Camels are raised for milk, meat, fiber (wool and hair), transport, and other work, and their dung is used as fuel (Elagamy, 2006). A Food and Agriculture Organization workshop estimated that global camel milk production exceeds approximately $5.3 \times 10^{9} \mathrm{~kg} / \mathrm{yr}$ (Al haj and Al Kanhal, 2010).

Products made from camel milk, including pasteurized camel milk, ice cream, cheese, camel milk powder, latte coffee, and camel milk soap, have been developed and sold in many countries (Al haj and Al Kanhal, 2010). Khalesi et al. (2017) reported that communities in arid rural regions of Asia and Africa use camel milk as a biomedicine to treat several health issues, such as asthma, edema, and diabetes. Camel milk contains high levels of vitamin $\mathrm{C}$ and niacin and is richer in $\mathrm{Cu}$ and Fe than bovine milk (Elagamy, 2006). The nutritional benefits of camel milk have been well stated (Al haj and Al Kanhal, 2010; Mostafa et al., 2013; Ahmed et al., 2014) despite the few limitations reported by Mihic et al. (2016). Camel milk contains well-balanced nutrients and biological components for fermented milk production. Moreover, camel milk is similar to human milk in terms of lack of $\beta-\mathrm{LG}$, but it contains $\alpha$-LA (Khalesi et al., 2017).

Probiotic lactic acid bacteria (LAB) are classified as homofermentative and heterofermentative based on metabolism pathways. In homofermentative LAB, probiotics ferment sugars to produce mainly lactic acid under anaerobic conditions (de Souza Oliveira et al., 2012b). In heterofermentative LAB, sugars are fermented to produce ethanol, $\mathrm{CO}_{2}$, and less lactic acid (de Souza Oliveira et al., 2012a). Functional milk products (bovine or camel milk) with health-promoting benefits are fermented by probiotic LAB (Shori, 2017). The in vitro health-promoting benefits of fermented camel milk have also been reported (El-Salam and ElShibiny, 2013). Researchers have focused only on the angiotensin-converting enzyme (ACE) inhibition and antioxidant activities of fermented camel milk (Shori, 
2013; Alhaj et al., 2017). Few attempts have been made to compare the health-promoting benefits of fermented camel milk with the benefits of other fermented mammalian milks, particularly fermented bovine milk (Mymensingh, 2007; Moslehishad et al., 2013; Shori, 2013), with an emphasis on ACE inhibition, antioxidant, and proteolytic activities. Shori and Baba (2014) examined the in vitro antidiabetics and antioxidant activities of fermented camel milk supplemented with garlic extract. The authors used traditional LAB such as Lactobacillus bulgaricus and Streptococcus thermophilus to ferment camel milk.

To the best of our knowledge, none of the above studies provided a comprehensive in vitro investigation into the health-promoting benefits (antiproliferation, antidiabetic, ACE inhibition, antioxidant, and proteolytic activities) of camel milk fermented with probiotic LAB isolated from camel milk. The current study attempted to highlight the effect of some chemical and biochemical variations between fermented camel and bovine milks with regard to potential health benefits. Abushelaibi et al. (2017) have isolated and identified 9 LAB from camel milk with robust probiotic characteristics. Lactococcus lactis KX881782 (Lc.K782) was found to be among the promising probiotics and therefore was used in the current study.

The aim of this study was to investigate in vitro the health-promoting benefits-namely antiproliferation activity against 3 cancer cell lines; $\alpha$-amylase and $\alpha$-glucosidase inhibitions; and antioxidant, $\mathrm{ACE}$ inhibition, and proteolytic activities - of camel milk fermented with Lc.K782 compared with fermented bovine milk during $21 \mathrm{~d}$ of storage at $4^{\circ} \mathrm{C}$. Lactobacillus acidophilus, a well-recognized probiotic, was used as a control.

\section{MATERIALS AND METHODS}

All chemicals used in this study were purchased from Sigma-Aldrich (St. Louis, MO) unless otherwise mentioned.

\section{Culture Propagation}

Lactobacillus acidophilus DSM9126 (La.DSM) was used as probiotic by several studies (Al-Saleh et al., 2006; Tareb et al., 2013); therefore, La.DSM was used in this study as a control. The La.DSM was purchased from Leibniz-Institute DSMZ-Deutsche Sammlung von Mikroorganismen und Zellkulturen GmbH (Braunschweig, Germany). The Lc.K782 was among the best probiotics that have been isolated from camel milk by Abushelaibi et al. (2017). The probiotic strains La.DSM and Lc.K782 were stored in de Man, Rogosa and Sharpe (MRS) broth (LAB M, Lancashire, UK) with $50 \%$ glycerol at $-80^{\circ} \mathrm{C}$. For culture activation, a $100-\mu \mathrm{L}$ aliquot of each culture was individually transferred into MRS broth and incubated at $37^{\circ} \mathrm{C}$ for $24 \mathrm{~h}$. A weekly culture transfer was carried out to maintain the bacterial activity. For all cultures, 2 successive culture transfers were carried out in MRS broth, and a third transfer was carried out in sterilized reconstituted skim bovine or camel milk ( $10 \% \mathrm{wt} / \mathrm{vol})$ and incubated at $37^{\circ} \mathrm{C}$ for $24 \mathrm{~h}$.

\section{Milk Fermentation}

Skim camel milk from 1-humped Camelus dromedarius was purchased from a local supplier with TS of approximately $10.3 \%$, protein content of $3.7 \%$, lactose content of $4.1 \%$, and fat content of $0.47 \%$ (wet base). Reconstituted skim bovine milk was prepared with TS of $10 \%$ (wt/vol), protein content of $3.4 \%$, lactose content of $4.5 \%$, and fat content of $0.5 \%$. The reconstituted skim bovine milk was used to ensure that the TS of the control was similar to the TS in the skim camel milk. Both milk types were pasteurized at $90^{\circ} \mathrm{C}$ for $10 \mathrm{~min}$ followed by cooling at $37^{\circ} \mathrm{C}$. Pasteurized milk was inoculated with $1 \%$ (wt/vol) of each strain separately $\left(\sim 9.0 \log _{10} \mathrm{cfu} / \mathrm{mL}\right)$ followed by mixing for 1 min. Inoculated milk was fermented at $37^{\circ} \mathrm{C}$ for 24 h. Afterward, fermented milk was cooled to $4^{\circ} \mathrm{C}$ in an ice bath and then stored at $4^{\circ} \mathrm{C}$ for $21 \mathrm{~d}$. Fermented milk was sampled at $0,7,14$, and $21 \mathrm{~d}$ of storage. Milk fermentation was performed in triplicate.

\section{Bacterial Enumeration}

The bacterial population in fermented milk was enumerated according to Sah et al. (2014). An aliquot (1 $\mathrm{mL}$ ) of blended fermented milk sample was subjected to appropriate serial dilutions using $0.1 \%$ (wt/vol) peptone (LAB M), and bacterial populations were counted using MRS agar (LAB M). Inoculated plates in duplicate were incubated anaerobically at $37^{\circ} \mathrm{C}$ for $48 \mathrm{~h}$ using an anaerobic jar system (Don Whitley Scientific Ltd., West Yorkshire, UK).

\section{Titratable Acidity}

Titratable acidity (TA) was carried out according to the method detailed in Kosikowski and Mistry (1977). Total acidity expressed as lactic acid percentage was determined by titrating samples with $0.01 \mathrm{~N} \mathrm{NaOH}$. 


\section{Water-Soluble Extract}

For each fermented milk sample, $\mathrm{pH}$ was adjusted with $1.0 \mathrm{M} \mathrm{HCl}$ or $1.0 M \mathrm{NaOH}$ to $\mathrm{pH} 4.6$, followed by centrifugation at $9,000 \times g$ for $15 \mathrm{~min}$ at $4^{\circ} \mathrm{C}$. The supernatants were filtered through a $0.45-\mu \mathrm{m}$ syringe filter (mixed cellulose esters, EMD Millipore Corp., Billerica, MA) and stored at $-20^{\circ} \mathrm{C}$ for further analysis.

\section{Proteolytic Activity Assay by o-Phthalaldehyde}

Prior to the o-phthalaldehyde (OPA) assay, stored water-soluble extracts (WSE) were vortexed for $1 \mathrm{~min}$ followed by centrifugation at $10,000 \times g$ for $5 \mathrm{~min}$. The OPA of WSE was determined as described by Sah et al. (2014). The absorbance was measured after exactly 2 min at $340 \mathrm{~nm}$ using a UV spectrophotometer (Jenway 6300, Cole-Parmer, Staffordshire, UK). Proteolysis results are presented as absorbance at $340 \mathrm{~nm}$.

\section{Antidiabetic Activities}

$\alpha$-Amylase Inhibition Assay. Prior to the assay, stored WSE were prepared as described. The $\alpha$-amylase inhibition assay was carried out according to the method described by Kim et al. (2004) with minor modifications. Briefly, $100 \mu \mathrm{L}$ of $\alpha$-amylase from human saliva (1.0 unit/mL) was premixed with $100 \mu \mathrm{L}$ of WSE. After preincubation at $37^{\circ} \mathrm{C}$ for $5 \mathrm{~min}, 250 \mu \mathrm{L}$ of $1 \%$ starch was added as a substrate in phosphate buffer solution $(\mathrm{pH}$ 6.8) to start the reaction. The reaction was performed at $37^{\circ} \mathrm{C}$ for 5 min and terminated by the addition of $200 \mu \mathrm{L}$ of DNS reagent (1\% 3,5-dinitrosalicylic acid and $12 \%$ sodium potassium tartrate in $0.4 \mathrm{M}$ $\mathrm{NaOH})$. The reaction mixture was heated for $15 \mathrm{~min}$ at $100^{\circ} \mathrm{C}$ and diluted with $2 \mathrm{~mL}$ of distilled water in an ice bath. $\alpha$-Amylase activity was determined by measuring absorbance at $540 \mathrm{~nm}$.

$\alpha$-Glucosidase Inhibition Assay. Prior to the assay, stored WSE were prepared as described above. $\alpha$-Glucosidase inhibition assay was carried out according to the method detailed in Kim et al. (2004) with some modifications. $\alpha$-Glucosidase ( 1 unit/mL; SigmaAldrich) was dissolved in $100 \mu \mathrm{L}$ of $0.1 \mathrm{M}$ potassium phosphate buffer $(\mathrm{pH} 6.8)$ and mixed with $50 \mu \mathrm{L}$ of WSE. After preincubation at $37^{\circ} \mathrm{C}$ for $10 \mathrm{~min}, 50 \mu \mathrm{L}$ of $5 \mathrm{~m} M$ p-nitrophenyl $\alpha$-D-glucopyranoside (pNPG) was added as the substrate. The enzymatic reaction was performed at $37^{\circ} \mathrm{C}$ for $30 \mathrm{~min}$ and stopped by the addition of $1 \mathrm{~mL}$ of $0.1 \mathrm{M} \mathrm{Na}_{2} \mathrm{CO}_{3}$. $\alpha$-Glucosidase activity was determined by measuring the release of $p$-nitrophenol from $\mathrm{pNPG}$ at $400 \mathrm{~nm}$. A solution without the WSE sample was used as a control. A solution without the substrate was used as a blank. The inhibition percentage of the $\alpha$-glucosidase was calculated.

\section{Antioxidant Activity}

Prior to the antioxidant assays, stored WSE were prepared as described above.

Radical Scavenging Rate by 1,1-Diphenyl2-Picrylhydrazyl Assay. The determination of radical scavenging activity by the 1,1-diphenyl-2-picrylhydrazyl (DPPH) assay was performed according to Elfahri et al. (2016).

Radical Scavenging Rate by 2,2'-Azino-Bis(3Ethylbenzo-Thiazoline-6-Sulphonic Acid) Assay. Radical scavenging rate by the 2,2 '-azino-bis(3ethylbenzo-thiazoline-6-sulphonic acid) $\quad\left(\right.$ ABTS $\left.^{\bullet+}\right)$ method was determined according to the procedure of Al-Dhaheri et al. (2017). Radical scavenging activity was calculated and expressed as percentages.

\section{Antihypertensive by ACE Inhibition}

The ACE-inhibition activity of WSE was assayed according to methods detailed in Ayyash and Shah (2011). The ACE inhibition was expressed as percentages.

\section{Anticancer by Antiproliferative Activity}

Prior to the assay, WSE were filtered through a Macrosep Advance spin filter (3 kDa; Pall Corp., Port Washington, NY). Filtrates were assayed against Caco2 and MCF-7 carcinoma cell lines according to the method detailed by Ayyash et al. (2018). Cell lines used for the cell cytotoxicity assay included colon cancer cell line Caco-2 (provided by Carine Platat, Nutrition and Health Department, United Arab Emirates University, Al Ain) and breast cancer cell line MCF-7 (provided by Faculty of Medicine and Health Sciences, United Arab Emirates University). Cells were grown in a humidified incubator $\left(37^{\circ} \mathrm{C}\right.$ and $\left.5 \% \mathrm{CO}_{2}\right)$ in Dulbecco's Modified Eagle medium (Gibco, Invitrogen, Carlsbad, CA) supplemented with $10 \%$ heat-inactivated bovine serum and $1 \%$ penicillin and streptomycin (Invitrogen). Cell lines were initially passaged and counted in a hemocytometer before seeding. Cells were seeded at $1 \times$ $10^{3}$ concentration in a 96-well plate and incubated in an appropriate medium overnight. For the treatment, $25 \mu \mathrm{L}$ of filtered WSE was added to each well and incubated for $72 \mathrm{~h}$ at $37^{\circ} \mathrm{C}$ and $5 \% \mathrm{CO}_{2}$. Afterward, $20 \mu \mathrm{L}$ of a prewarmed cell cytotoxicity assay kit (ab112118, Abcam, Cambridge, UK) was added and incubated at $37^{\circ} \mathrm{C}$ for a minimum of $5 \mathrm{~h}$. Each sample was assayed 
Table 1. Bacterial population, $\mathrm{pH}$ values, and titratable acidity of fermented camel and bovine milks ${ }^{1,2}$

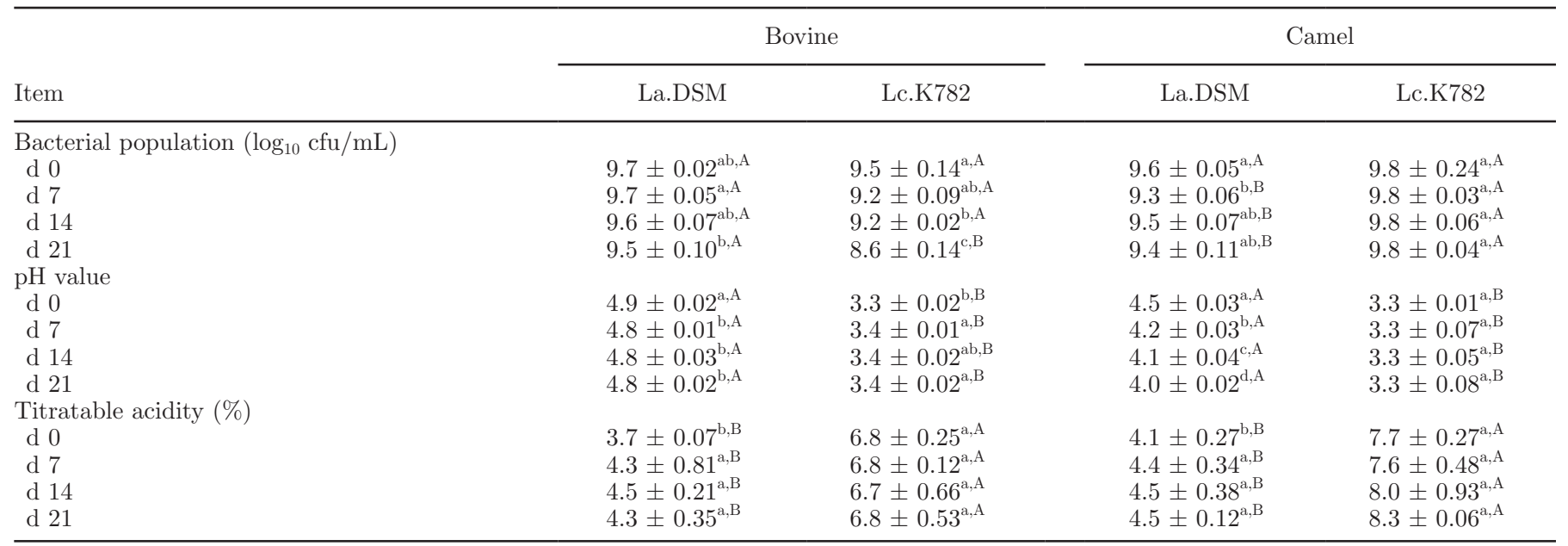

${ }^{\mathrm{a}-\mathrm{d}}$ Means in the same column and within a variable with different superscripts differ $(P<0.05)$.

${ }^{\mathrm{A}, \mathrm{B}}$ Means of the same milk in the same row with different superscripts differ $(P<0.05)$.

${ }^{1}$ Values are mean $\pm \mathrm{SD}$ of $\mathrm{n}=6$.

${ }^{2}$ La.DSM $=$ Lactobacillus acidophilus DSM9126; Lc.K782 = Lactococcus lactis KX881782.

in triplicate. The absorbance [optical density (OD)] was measured at 570 and $605 \mathrm{~nm}$ according to the kit manufacturer's protocol. The ratio of OD570/OD605 $\mathrm{nm}$ was used to assess cell viability in each well. The proliferative inhibition was calculated as follows:

$$
\text { antiproliferative }(\%)=\left[1-\frac{\text { Rsample }- \text { Ro }}{\text { Rctrl }- \text { Ro }}\right] \times 100,
$$

where Rsample is the absorbance ratio of OD570/ OD605 in the presence of the WSE, Rctrl is the absorbance ratio of OD570/OD605 in the absence of the WSE (vehicle control), and Ro is the averaged background (noncell control) absorbance ratio of OD570/ OD605.

\section{Statistical Analysis}

All fermentation experiments $(2$ milk types $\times 2$ probiotics $\times 4$ storage times) were conducted in triplicate on 3 different occasions. Each sample was assayed in duplicate unless otherwise mentioned. Two-way ANOVA was carried out to investigate the effects of probiotic strain and storage period on fermented milk parameters $(P<0.05)$ within the same milk type. Mean comparisons were performed using Tukey's test $(P<$ 0.05). Pearson's test was carried out to find any correlations between parameters for the same milk and the same probiotic bacterium. Correlation coefficients are presented in Supplemental Tables S1 and S2 (https:// doi.org/10.3168/jds.2017-13400) for milk fermented by La.DSM and Lc.K782, respectively. All statistical analyses were carried out using Minitab 17.0 software (Minitab Inc., State College, PA).

\section{RESULTS AND DISCUSSION}

\section{Bacterial Population, $\mathrm{pH}$, and TA}

The bacterial population $\left(\log _{10} \mathrm{cfu} / \mathrm{mL}\right), \mathrm{pH}$ values, and TA (\%) of fermented bovine and camel milk during $21 \mathrm{~d}$ of storage at $4^{\circ} \mathrm{C}$ are presented in Table 1 . In both milk types, the bacterial populations of both strains were maintained at $>8.5$ logs during the storage period. The bacterial population of Lc.K782 was higher $(P<$ 0.05) than that of La.DSM in fermented camel milk during all storage periods.

Table 1 shows that $\mathrm{pH}$ values of milk fermented by Lc.K782 were significantly lower $(P<0.05)$ than those of milk fermented by La.DSM during the storage period. Consistently, percentages of TA in both milk types fermented by Lc.K782 were higher $(P<0.05)$ than percentages of TA in the milks fermented by La.DSM. In general, $\mathrm{pH}$ and $\mathrm{TA}$ in both milk types fermented by Lc.K782 differed insignificantly $(P>0.05)$ during the storage period, whereas the $\mathrm{pH}$ decreased $(P<0.05)$ and TA percentage increased $(P<0.05)$ in bovine and camel milks fermented by La.DSM (Table 1).

According to the FAO/WHO (2002) definition of probiotics, a high probiotic population in fermented milk, especially at the time of consumption, is required. Our results are in accordance with the FAO/WHO (2002) guidelines for probiotics. The present results also agree 
with findings by Moslehishad et al. (2013), who reported that the bacterial population maintained at $>8.0 \operatorname{logs}$ in camel and bovine milks fermented by Lactobacillus rhamnosus PTCC 1637. The relatively lower bacterial population of La.DSM in fermented camel milk may be attributed to less ability of La.DSM to overcome the antimicrobial components in fermented camel milk. Elagamy et al. (1996) found that the antimicrobial quantities in camel milk were higher than in bovine milk. We presume that Lc.K782 were more compatible with camel milk than La.DSM. This may be because Lc.K782 was isolated from camel milk (Abushelaibi et al., 2017). These antimicrobial components had bacteriostatic effects on probiotics but not bactericidal effects (Elagamy, 2006).

The current $\mathrm{pH}$ and TA percentage results had negative (inverse) correlations for both milk types fermented by Lc.K872 (Supplemental Table S2). The lower pH and higher TA percentages of both fermented milks by Lc.K782 may be attributed to the higher efficiency of Lc.K782 to ferment lactose into lactic acid. We assume that lactose fermentation by Lc.K782 was via homofermentation. Homolactic fermentation produces more lactic acid than heterofermentation (Marshall and Tamime, 1997). Although camel milk is known to have more natural antimicrobial substances than bovine milk (Elagamy et al., 1996), Lc.K782 had a further capacity to produce more organic acids (higher TA percentage) in fermented camel milk than in bovine milk. The TA percentage results agree with the findings of Monteagudo-Mera et al. (2011), who reported a significant difference in acidity between fermented ewe and cow milk after $6 \mathrm{~h}$ of fermentation using the same strain. Our results also agree with the report of Abu-Tarboush (1996), who showed clear differences in $\mathrm{pH}$ between fermented camel and cow milk. Dahi yogurt prepared from cow, goat, and buffalo milk and fermented by the same strain had different acidity (Mymensingh, 2007). However, these studies did not provide satisfactory interpretations for their findings. On the other hand, Shori and Baba (2014) and Gomes et al. (2013) reported insignificant differences in acidity between cow and camel or ewe milk, respectively. We postulate that the higher TA percentage in fermented camel milk may be attributed to the adaptation of the Lc.K782 strain to camel milk because these strains were isolated from camel milk.

\section{Proteolysis Assessment by OPA}

The proteolytic patterns of bovine and camel milks fermented by La.DSM and Lc.K782 during $21 \mathrm{~d}$ of storage at $4^{\circ} \mathrm{C}$ are shown in Figure 1. Remarkably, camel milk fermented by Lc.K782 had greater $(P<0.05)$ OPA readings than bovine milk during the storage period. Bovine milk fermented by La.DSM had higher $(P$ $<0.05)$ OPA absorbance at d 14 and 21 of storage than fermented camel milk (Figure 1). In general, proteolytic activity in both fermented milk types increased significantly $(P<0.05)$ with prolonged storage (Figure 1$)$. In camel milk fermented by Lc.K782, OPA correlated positively with bacterial population $(\mathrm{r}=0.717)$ and

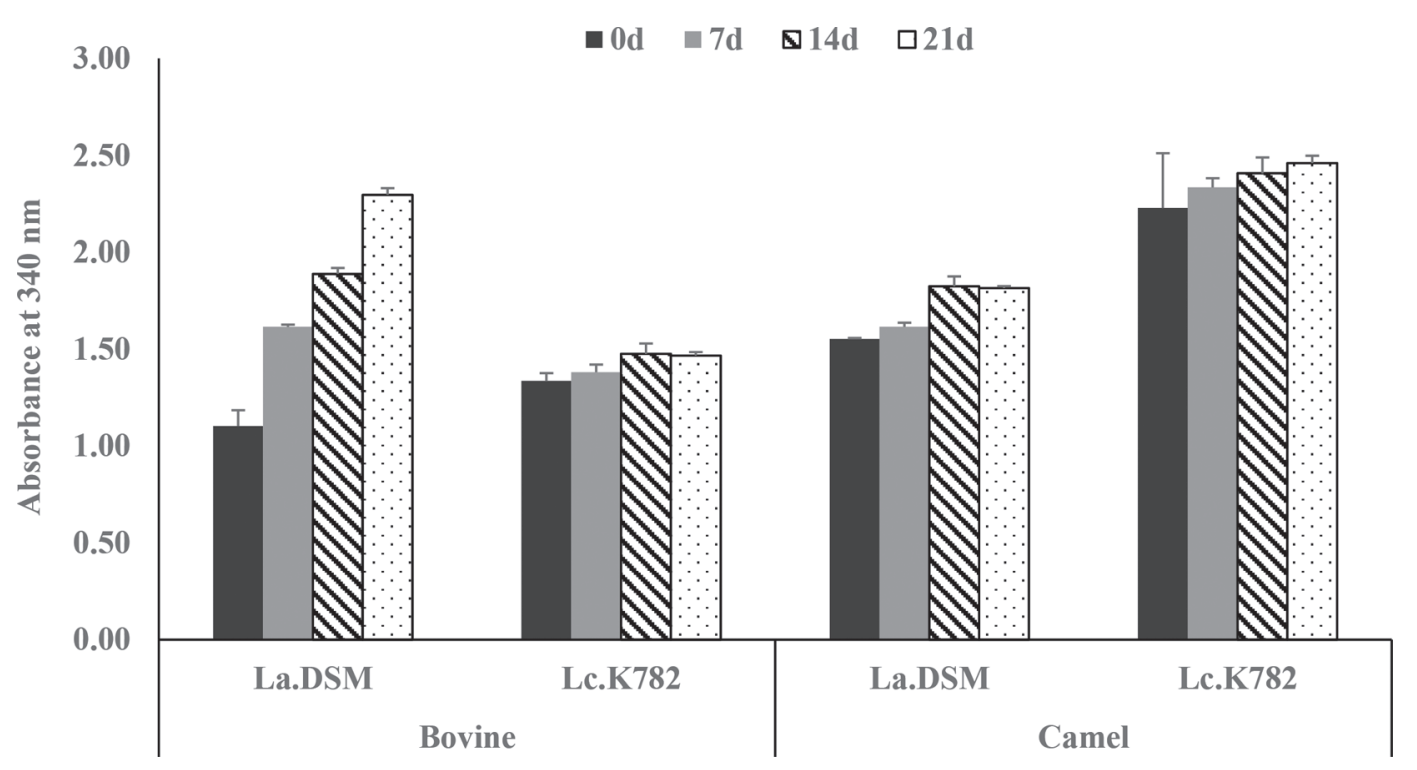

Figure 1. Proteolytic activity of fermented camel and bovine milks measured by $o$-phthalaldehyde at $340 \mathrm{~nm}$. Values are mean $\pm \mathrm{SD}$ of $\mathrm{n}=$ 6. La.DSM = Lactobacillus acidophilus DSM9126; Lc.K782 = Lactococcus lactis KX881782. 
TA $(\mathrm{r}=0.531)$ and correlated negatively with $\mathrm{pH}(\mathrm{r}=$ -0.207; Supplemental Table S2).

Proteolytic activity is an exploratory indicator of the presence of the bioactive compounds, especially small peptides, that could be connected to the healthpromoting benefits in the fermented product (Hailu et al., 2016; Brown et al., 2017; Marco et al., 2017). McSweeney and Fox (1997) reported that OPA assesses small peptides and free AA in the fermented product. One major group of bioactive compounds in fermented dairy products are oligopeptides (Park, 2009). Consequently, the high OPA results in camel milk fermented by Lc.K782 may improve health-promoting benefits compared with La.DSM. Several proteolytic enzymes (proteinases, peptidases, and aminopeptidases) are produced by LAB, including Lactococcus (Park, 2009). The higher OPA in camel milk than in bovine milk fermented by Lc.K782 (Figure 1) may be attributed to the susceptibility of camel milk caseins to proteolytic enzymes produced by the Lc.K782 strain used. These results agree with those of Shori and Baba (2014), who reported higher OPA values in fermented plain (without garlic extract) camel milk than in plain bovine milk. Abu-Tarboush (1996) also reported higher proteolytic activity in camel milk fermented by Streptococcus thermophilus and Lb. bulgaricus than in fermented bovine milk.

The lower OPA (Figure 2) in camel milk fermented by La.DSM than in that fermented by Lc.K782 suggests that the latter has stronger proteolytic capabilities than the control strain (La.DSM). The comparatively strong positive correlations between OPA and TA percentage and bacterial population in fermented camel milk support the assumption that proteolytic activity and lactose metabolism by Lc.K782 increased in camel milk compared with bovine milk.

\section{Antidiabetic by a-Amylase and $\alpha$-Glucosidase Inhibition}

The inhibition results of $\alpha$-amylase and $\alpha$-glucosidase as indicators for antidiabetic activities of bovine and camel milks fermented by La.DSM and Lc.K782 are illustrated in Figure 2A and 2B, respectively. In general, the $\alpha$-amylase inhibitions were $>40 \%$ in bovine milk fermented by La.DSM and camel milk fermented by Lc.K782 during all storage periods (Figure 2A). Noteworthy, the inhibition of $\alpha$-amylase increased $(P<$ $0.05)$ with prolonged storage in camel milk fermented by both strains, whereas the changes in $\alpha$-amylase inhibition in fermented bovine milk were insignificant $(P$ $>0.05$ ). Comparatively, the percentages of $\alpha$-amylase inhibitions in camel milk fermented by Lc.K782 were greater $(P<0.05)$ than in bovine milk (Figure $2 \mathrm{~A}$ ).
The inhibitions of $\alpha$-glucosidase in both milks fermented by Lc.K782 were higher $(P<0.05)$ than milks fermented by La.DSM in the same milk type (Figure 2B). The $\alpha$-glucosidase inhibitions in both milks fermented by Lc.K782 ranged from 30 to $40 \%$, whereas the $\alpha$-glucosidase inhibitions in both milks fermented by La.DSM were $<30 \%$. $\alpha$-Glucosidase inhibitions differed insignificantly $(P>0.05)$ during storage. Pearson's test showed that $\alpha$-amylase inhibition in both milks fermented by Lc.K782 correlated positively with OPA (Supplemental Table S2). The correlations between $\alpha$-amylase and $\alpha$-glucosidase inhibitions in bovine $(\mathrm{r}$ $=0.264)$ and camel $(\mathrm{r}=-0.388)$ milks fermented by Lc.K782 were weak (Supplemental Table S2).

The inhibition of $\alpha$-amylase and $\alpha$-glucosidase activities is an indirect indicator to assess the antidiabetic properties of the current fermented products (Donkor et al., 2012). It has been reported that the inhibition of $\alpha$-amylase and $\alpha$-glucosidase reduces carbohydrate hydrolysis, which in turn reduces the possibility of sugars being absorbed by the human intestine (Layer et al., 1986). The general inhibition of both $\alpha$-amylase and $\alpha$-glucosidase enzymes may be attributed to bioactive peptides, particularly small ones (Gomes da Cruz et al., 2009), produced as a consequence of proteolytic enzymes secreted by the current strains. Our results contradict findings by Shori and Baba (2014), who reported that fermented plain camel milk had higher $\alpha$-amylase and $\alpha$-glucosidase inhibitions than fermented plain cow milk. We assume that this contradiction may be attributed to differences in bioactive peptides released in fermented milk between the current study and that of Shori and Baba (2014). The differences in LAB species and strains could lead to variations in proteolytic activity qualitatively and quantitatively (El-Salam and ElShibiny, 2013). The noticeable $\alpha$-glucosidase inhibitions in both milk types fermented by Lc.K782 may be attributed to the nature of bioactive peptides released in milk fermented by Lc.K782. Moslehishad et al. (2013) reported that the peptide functionality varied according to the peptide fractions. The authors demonstrated that peptide fractions $<3 \mathrm{kDa}$ had a higher bioactivity than fractions of 3 to $5 \mathrm{kDa}$. The positive correlation between OPA and $\alpha$-amylase inhibition in both milks fermented by Lc.K782 improves the suggestion that Lc.K782 has promising probiotic and industrial characteristics.

\section{Antioxidant Activities by ABTS and DPPH}

The scavenging rates of bovine and camel milks fermented by La.DSM and Lc.K782 are presented in Figure $3 \mathrm{~A}$ for DPPH and Figure 2B for ABTS. In general, both milks fermented by Lc.K782 had higher $(P$ 

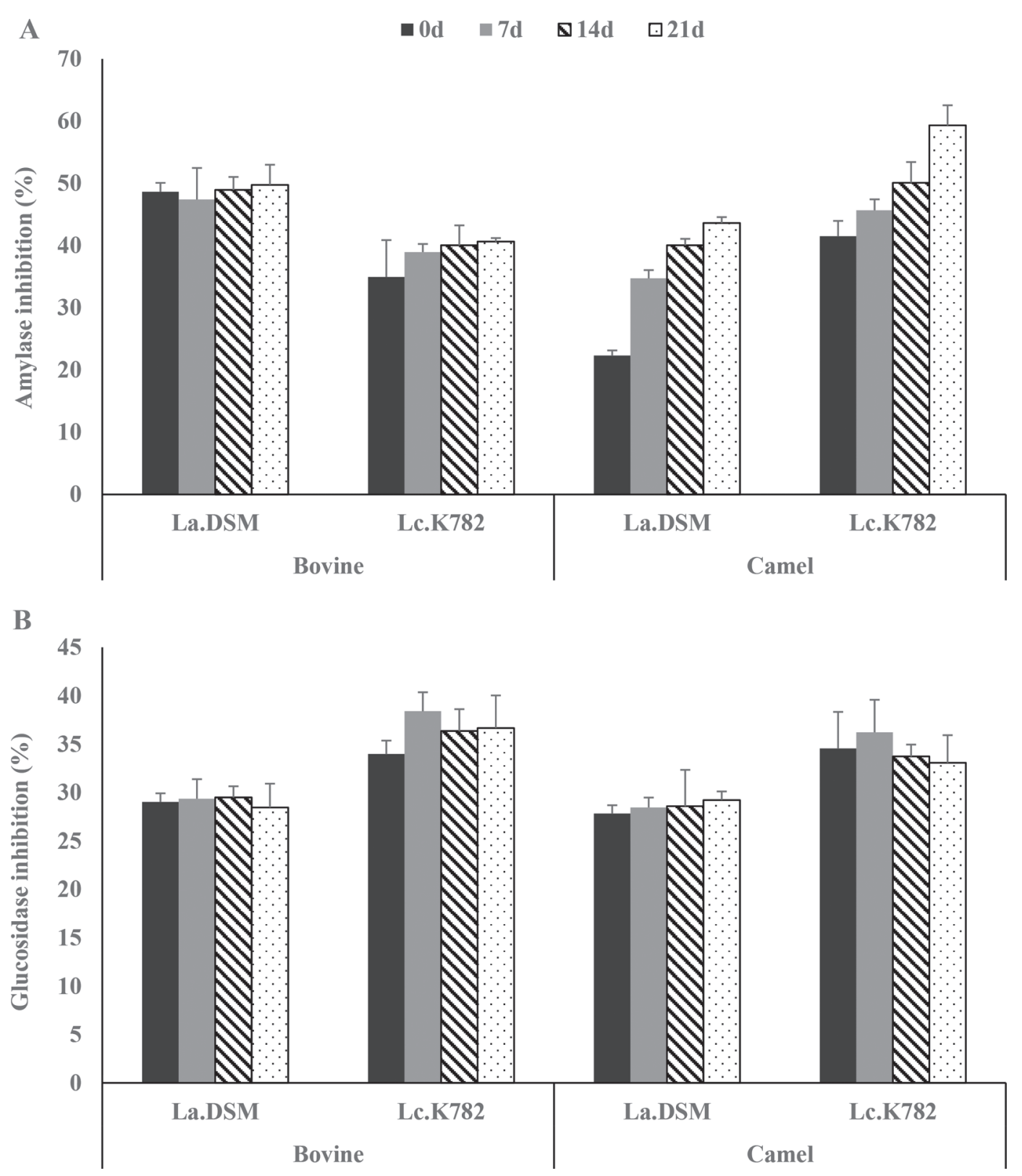

Figure 2. (A) $\alpha$-Amylase inhibition and (B) $\alpha$-glucosidase inhibition of fermented camel and bovine milks. Values are mean \pm SD of $\mathrm{n}=6$. La.DSM = Lactobacillus acidophilus DSM9126; Lc.K782 = Lactococcus lactis KX881782.

$<0.05)$ antioxidant activities by DPPH than those fermented by La.DSM. Figure 3A shows that camel milk fermented by Lc.K782 possessed the highest DPPH rates compared with La.DSM, which ranged from $30 \%$ at $0 \mathrm{~d}$ to $>50 \%$ at the end of storage. Camel milk fermented by La.DSM demonstrated a very low DPPH antioxidant activity compared with fermented bovine milk (Figure 3A).

Antioxidant activity by ABTS were significantly higher in fermented camel milk than in fermented bovine milk (Figure 3B). Consistent with DPPH, camel milk fermented by Lc.K782 had the highest $(P<0.05)$ ABTS percentages compared with the fermented counterparts. In contrast to DPPH, camel milk fermented by La.DSM showed higher $(P<0.05)$ ABTS percentage than fermented bovine milk (Figure 3B). In general, antioxidant activity by ABTS differed insignificantly $(P>0.05)$ during the storage period except that for bovine milk fermented by La.DSM. In camel milk fermented by Lc.K782, DPPH correlated positively and ABTS correlated negatively with OPA and TA percentage (Supplemental Table S2). In both milks fermented 

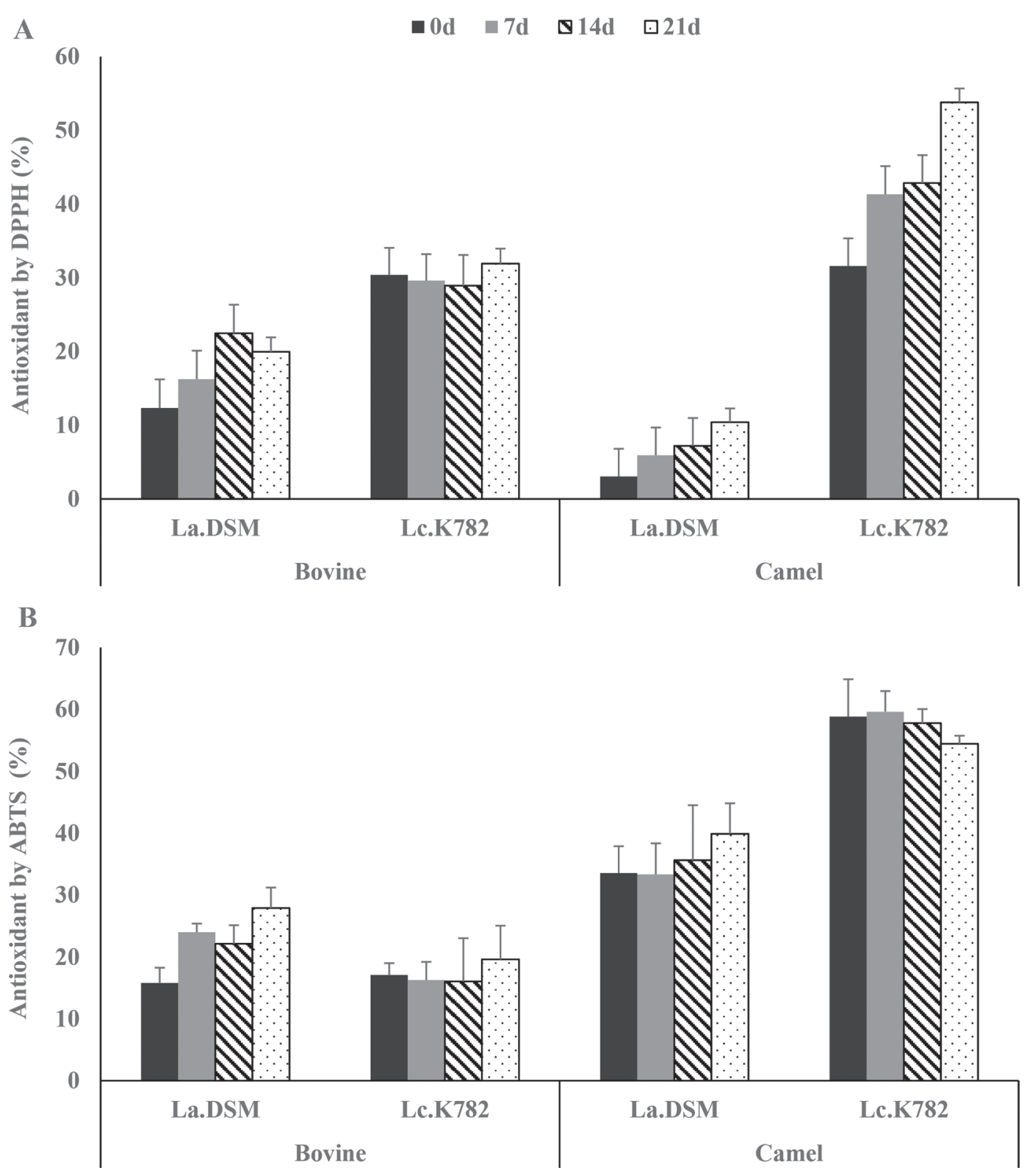

Figure 3. Antioxidant activities by (A) 1,1-diphenyl-2-picrylhydrazyl (DPPH) and (B) 2,2'-azino-bis(3-ethylbenzo-thiazoline-6-sulphonic acid) (ABTS) of fermented camel and bovine milks. Values are mean \pm SD of $\mathrm{n}=6$. La.DSM = Lactobacillus acidophilus DSM9126; Lc.K782 = Lactococcus lactis KX881782.

by Lc.K782, ABTS and DPPH had negative correlations (Supplemental Table S2). Different trends in antioxidant activities of camel and bovine milks could be attributed to the different mechanisms of action for the 2 assays used (ABTS and DPPH).

Bioactive compounds in foods, especially fermented dairy products, play a crucial role in elevating the effect of reactive oxygen species such as superoxide $\left({ }^{\bullet} \mathrm{O}_{2}{ }^{-}\right.$, $\bullet \mathrm{OOH})$, hydroxyl $\left({ }^{\bullet} \mathrm{OH}\right)$, and peroxyl $\left(\mathrm{ROO}^{\bullet}\right)$ radicals formed by oxidatively stressed cells (Benbrook, 2005). These bioactive compounds, especially protein-derived peptides, possess the ability to donate electrons to neutralize the free radicals. Moreover, the presence of several AA residues in the peptide chains can enhance antioxidant properties (Aluko, 2012). Bioactive peptides, as antioxidant agents, in fermented milk prevent enzymatic and nonenzymatic peroxidation of essential fatty acids (El-Salam and El-Shibiny, 2013). The higher antioxidant activities in fermented camel milk than in bovine milk may be attributable to higher proteolysis rate (high OPA; Figure 1) and the nature of bioactive peptides in fermented camel milk. Similarly, Moslehi- 
shad et al. (2013) reported higher antioxidant activity by ABTS assay in camel milk than in bovine milk fermented by Lb. rhamnosus PTCC 1637. Shori (2013) also reported similar antioxidant activity results by DPPH assay in fermented camel milk compared with bovine milk. The current results suggest that Lc.K782 has greater capabilities to produce antioxidant agents in fermented camel milk than La.DSM or bovine milk fermented by Lc.K782. This result may be attributed to the fact that Lc.K782 has been isolated from camel milk and thus Lc.K782 was more familiar with camel milk than bovine milk.

\section{ACE-Inhibition Activity}

Figure 4 illustrates that ACE inhibitions in camel milk fermented by Lc.K782 were significantly $(P<$ 0.05) higher than in bovine milk during all storage periods. The ACE inhibitions ranged from 80 to $90 \%$ and from 30 to $60 \%$ in camel milk fermented by Lc.K782 and La.DSM, respectively, whereas the ACE inhibition in bovine milk did not exceed 50\% during storage (Figure 4). The increases in ACE-inhibition activities in all fermented milk types during prolonged storage were significant $(P<0.05)$. In general, ACE inhibition in fermented camel milk exhibited positive correlations with proteolytic activities (OPA), TA percentage, and antioxidant activity by DPPH (Supplemental Tables S1 and S2).

The ACE-inhibition activity is an in vitro indicator of antihypertensive properties of fermented dairy products
(Gobbetti et al., 2004). The higher ACE inhibition in camel milk may be attributed to high proteolytic activity (OPA; Figure 1). This supports our assumption that camel milk proteins were more susceptible to hydrolysis by proteolytic enzymes produced by the present strains except for Lc.K782. Moreover, the nature of peptides in camel milk fermented by both strains may contribute to the higher ACE inhibition than in bovine milk. ElSalam and El-Shibiny (2013) reported a higher proline content in camel caseins, which may explain the high ACE inhibition in fermented camel milk. The current results agree with those reported by Moslehishad et al. (2013), who reported greater ACE inhibition in camel milk than in bovine milk fermented by $L b$. rhamnosus. The ACE inhibitions of camel milk fermented by Lc.K782 were greater than those reported by Alhaj et al. (2017), who fermented camel milk by Lb. acidophilus and Streptococcus thermophiles or Lactobacillus helveticus. The positive correlation between ACE inhibition and antioxidant activity by DPPH suggests that the peptides released by the proteolytic action of Lc.K782 may possess multifunctional bioactivities (Harnedy and FitzGerald, 2012).

\section{Anticancer Activities}

Table 2 presents the antiproliferative activities, as an anticancer indicator, of WSE $(\leq 3 \mathrm{kDa})$ of fermented bovine and camel milks against Caco-2, MCF-7, and HELA carcinoma cell lines. The proliferations of Caco-2, MCF-7, and HELA cells were more inhibited

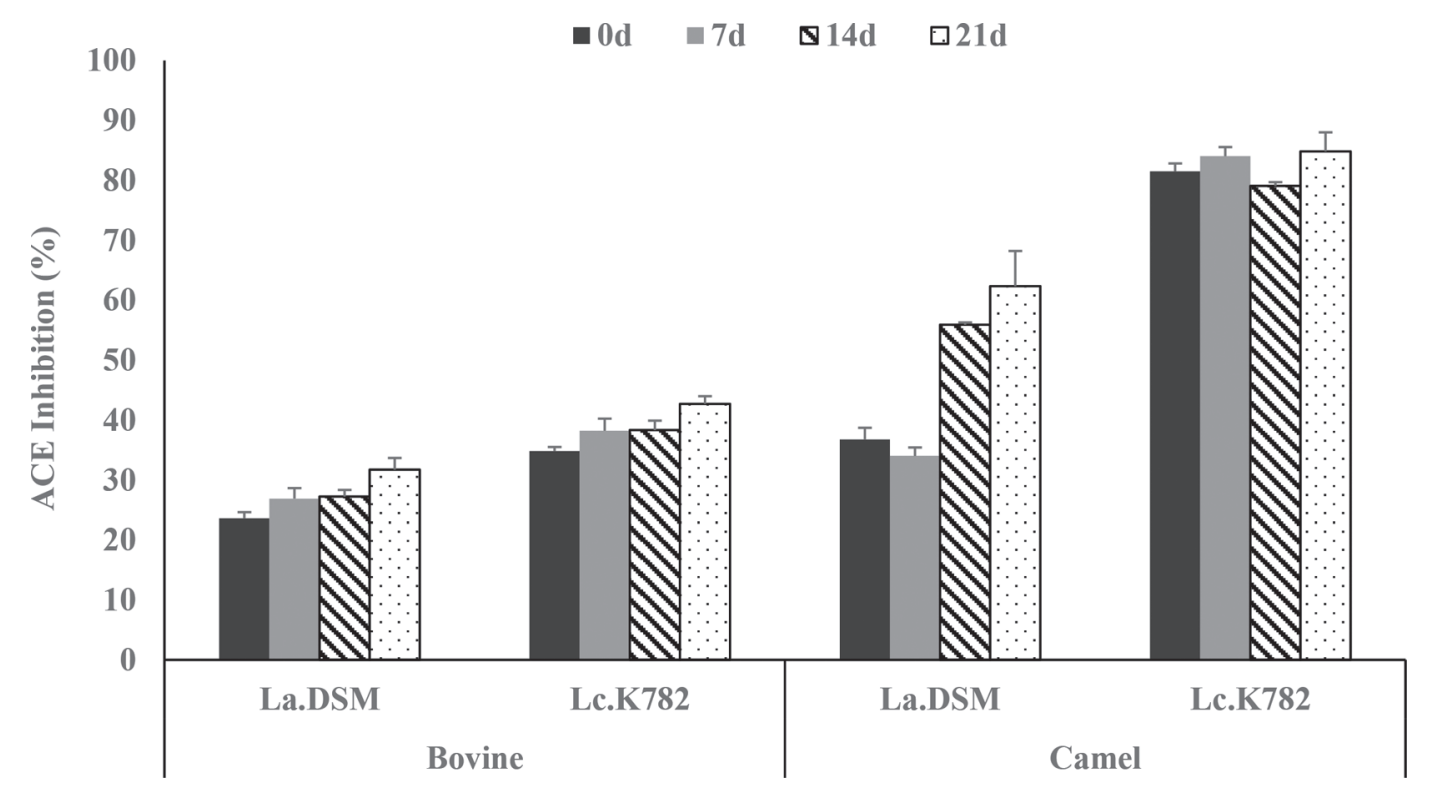

Figure 4. Angiotensin-converting enzyme (ACE) inhibition of fermented camel and bovine milks. Values are mean $\pm \mathrm{SD}$ of $\mathrm{n}=6$. La.DSM = Lactobacillus acidophilus DSM9126; Lc.K782 = Lactococcus lactis KX881782. 
Table 2. Antiproliferative activities (\%) of fermented bovine and camel milks against 3 cancer cell lines ${ }^{1,2}$

\begin{tabular}{lccccc}
\hline & \multicolumn{2}{c}{ Bovine } & & \multicolumn{2}{c}{ Camel } \\
\cline { 2 - 3 } \cline { 5 - 6 } Item & La.DSM & Lc.K782 & & La.DSM & Lc.K782 \\
\hline Caco-2 & & & & \\
d 0 & $37.0 \pm 1.01^{\mathrm{a}, \mathrm{B}}$ & $64.2 \pm 3.27^{\mathrm{a}, \mathrm{A}}$ & & $42.1 \pm 2.49^{\mathrm{a}, \mathrm{B}}$ & $86.3 \pm 0.76^{\mathrm{c}, \mathrm{A}}$ \\
d 7 & $37.3 \pm 0.25^{\mathrm{a}, \mathrm{B}}$ & $61.5 \pm 1.78^{\mathrm{a}, \mathrm{A}}$ & & $42.1 \pm 2.91^{\mathrm{a}, \mathrm{B}}$ & $87.9 \pm 0.83^{\mathrm{bc}, \mathrm{A}}$ \\
d 14 & $35.9 \pm 2.32^{\mathrm{a}, \mathrm{B}}$ & $63.3 \pm 3.28^{\mathrm{a}, \mathrm{A}}$ & & $38.4 \pm 0.31^{\mathrm{a}, \mathrm{B}}$ & $93.5 \pm 2.77^{\mathrm{a}, \mathrm{A}}$ \\
d 21 & $36.4 \pm 0.44^{\mathrm{a}, \mathrm{B}}$ & $63.0 \pm 1.48^{\mathrm{a}, \mathrm{A}}$ & & $42.5 \pm 1.13^{\mathrm{a}, \mathrm{B}}$ & $92.8 \pm 2.41^{\mathrm{ab}, \mathrm{A}}$ \\
MCF-7 & & & & \\
d 0 & $41.3 \pm 2.61^{\mathrm{a}, \mathrm{B}}$ & $80.9 \pm 0.51^{\mathrm{a}, \mathrm{A}}$ & & $37.1 \pm 0.59^{\mathrm{b}, \mathrm{B}}$ & $88.3 \pm 1.33^{\mathrm{a}, \mathrm{A}}$ \\
d 7 & $38.9 \pm 4.40^{\mathrm{a}, \mathrm{B}}$ & $80.3 \pm 1.64^{\mathrm{a}, \mathrm{A}}$ & & $40.4 \pm 2.35^{\mathrm{b}, \mathrm{B}}$ & $86.9 \pm 2.67^{\mathrm{a}, \mathrm{A}}$ \\
d 14 & $45.7 \pm 1.11^{\mathrm{a}, \mathrm{B}}$ & $78.9 \pm 0.17^{\mathrm{ab}, \mathrm{A}}$ & & $59.3 \pm 1.65^{\mathrm{a}, \mathrm{B}}$ & $93.4 \pm 1.51^{\mathrm{a}, \mathrm{A}}$ \\
d 21 & $51.2 \pm 7.88^{\mathrm{a}, \mathrm{B}}$ & $76.7 \pm 1.79^{\mathrm{b}, \mathrm{A}}$ & & $56.4 \pm 6.37^{\mathrm{a}, \mathrm{B}}$ & $91.5 \pm 5.71^{\mathrm{a}, \mathrm{A}}$ \\
HELA & & & & \\
d 0 & $40.5 \pm 1.34^{\mathrm{a}, \mathrm{B}}$ & $61.3 \pm 4.86^{\mathrm{a}, \mathrm{A}}$ & & $46.4 \pm 1.71^{\mathrm{a}, \mathrm{B}}$ & $90.0 \pm 1.87^{\mathrm{a}, \mathrm{A}}$ \\
d 7 & $46.9 \pm 6.15^{\mathrm{a}, \mathrm{B}}$ & $54.1 \pm 5.25^{\mathrm{a}, \mathrm{A}}$ & & $52.1 \pm 6.37^{\mathrm{a}, \mathrm{B}}$ & $88.2 \pm 2.29^{\mathrm{a}, \mathrm{A}}$ \\
d 14 & $50.5 \pm 4.50^{\mathrm{a}, \mathrm{B}}$ & $58.8 \pm 1.47^{\mathrm{a}, \mathrm{A}}$ & & $56.1 \pm 8.00^{\mathrm{a}, \mathrm{B}}$ & $86.8 \pm 1.76^{\mathrm{a}, \mathrm{A}}$ \\
d 21 & $49.6 \pm 2.14^{\mathrm{a}, \mathrm{B}}$ & $56.9 \pm 6.66^{\mathrm{a}, \mathrm{A}}$ & & $60.6 \pm 3.45^{\mathrm{a}, \mathrm{B}}$ & $87.4 \pm 2.31^{\mathrm{a}, \mathrm{A}}$ \\
\hline
\end{tabular}

${ }^{\mathrm{a}-\mathrm{c}}$ Means in the same column with different superscripts differ $(P<0.05)$.

${ }^{\mathrm{A}, \mathrm{B}}$ Means of the same milk in the same row with different superscripts differ $(P<0.05)$.

${ }^{1}$ Values are mean $\pm \mathrm{SD}$ of $\mathrm{n}=9$.

${ }^{2}$ La.DSM $=$ Lactobacillus acidophilus DSM9126; Lc.K782 = Lactococcus lactis KX881782.

$(P<0.05)$ when treated with WSE from both milks fermented by Lc.K782 compared with La.DSM. The WSE from camel milk fermented by Lc.K782 demonstrated greater $(P<0.05)$ antiproliferative activities than bovine milk fermented by the same strain (Table 2 ). In general, the changes in antiproliferative activities against all cell lines during prolonged storage were insignificant except bovine milk fermented by La.DSM against MCF-7 and camel milk fermented by Lc.K782 against Caco-2. In camel milk fermented by Lc.K782, proliferation inhibition of Caco-2 and MCF-7 had positive correlation with OPA, TA, and antioxidant activity by DPPH and negative correlation with $\mathrm{pH}$ (Supplemental Table S2). Pearson's test exhibited a weak correlation between proliferation inhibitions of 3 cell lines and ACE inhibition in both milks fermented by Lc.K782 (Supplemental Table S2).

The antiproliferation activities of milk peptides have been reported by several studies (Park, 2009). Several hypotheses have been proposed explaining the mechanism(s) of the antiproliferative activities of milk peptides. One of these hypotheses is that the released peptides have specific cytotoxicity on cancer cells, which induces apoptosis. Another hypothesis claims that there is competition between the peptides and cancer growth factors for cancer cell-membrane receptors (Picot et al., 2006; Pessione and Cirrincione, 2016). Therefore, the high antiproliferation activity of WSE in camel milk fermented by Lc.K782 may be attributed to greater competition capability of peptides derived from fermented camel milk compared with those from fermented bovine milk. The specific cytotoxicity of the fermented camel milk peptides to induce apoptosis may contribute to the interpretation. To the best of our knowledge, several works have reported antiproliferation activity of camel milk but without fermentation or comparison with bovine milk (Magjeed, 2005; Korashy et al., 2012; Habib et al., 2013). The remarkable antiproliferative activities in milk fermented by Lc.K782 may be attributed to novel fermentation properties of Lc.K782 as a new probiotic strain isolated from raw camel milk (Abushelaibi et al., 2017). The positive correlation between proliferation inhibition and $\mathrm{DPPH}$ suggests that peptides derived from fermented camel milk have multifunctional bioactivity.

\section{CONCLUSIONS}

This study showed that health-promoting benefits, particularly antioxidant, ACE-inhibition, and antiproliferative activities of WSE, in fermented camel milk were markedly higher than those in fermented bovine milk. Moreover, the WSE in camel milk fermented by indigenous LAB Lc.K782 exhibited greater potential health benefits than nonindigenous strains (La.DSM). The fermented camel milk requires more investigations to identify proteolytic pathways of the indigenous LAB isolated from camel milk and to characterize the bioactive peptides derived from fermented camel milk. The characteristics of Lc.K782 isolated from camel milk make it a promising starter culture for the dairy food industry. 


\section{ACKNOWLEDGMENTS}

The authors are grateful to Amna Al-Nuaimi (Food Science Department, United Arab Emirates University) for technical support. The authors acknowledge the financial support by United Arab Emirates University (Al Ain) via UAEU/SQU Joint Project G00002238.

\section{REFERENCES}

Abu-Tarboush, H. 1996. Comparison of associative growth and proteolytic activity of yogurt starters in whole milk from camels and cows. J. Dairy Sci. 79:366-371.

Abushelaibi, A., S. Al-Mahadin, K. El-Tarabily, N. P. Shah, and M. Ayyash. 2017. Characterization of potential probiotic lactic acid bacteria isolated from camel milk. Lebensm. Wiss. Technol. 79:316-325.

Ahmed, A. A.-H., R. G. Sayed, and M. Sayed. 2014. Nutritional value and sanitary evaluation of raw camel's milk. Emir. J. Food Agric. 26:317.

Al-Dhaheri, A. S., R. Al-Hemeiri, J. Kizhakkayil, A. Al-Nabulsi, A. Abushelaibi, N. P. Shah, and M. Ayyash. 2017. Health-promoting benefits of low-fat akawi cheese made by exopolysaccharide-producing probiotic Lactobacillus plantarum isolated from camel milk. J. Dairy Sci. 100:7771-7779.

$\mathrm{Al}$ haj, O. A., and H. A. Al Kanhal. 2010. Compositional, technological and nutritional aspects of dromedary camel milk. Int. Dairy J. 20:811-821.

Al-Saleh, A., A. Metwalli, and H. Abu-Tarboush. 2006. Bile salts and acid tolerance and cholesterol removal from media by some lactic acid bacteria and bifidobacteria. J. Saudi Soc. Food Nutr. 1:1-17.

Alhaj, O. A., A. A. Metwalli, E. A. Ismail, H. S. Ali, A. S. Al-Khalifa, and A. D. Kanekanian. 2017. Angiotensin converting enzyme-inhibitory activity and antimicrobial effect of fermented camel milk (Camelus dromedarius). Int. J. Dairy Technol. https://doi.org/10 $.1111 / 1471-0307.12383$

Aluko, R. E. 2012. Functional Foods and Nutraceuticals. Springer, New York, NY.

Ayyash, M., A. K. Al-Nuaimi, S. Al-Mahadin, and S.-Q. Liu. 2018. In vitro investigation of anticancer and ACE-inhibiting activity, $\alpha$-amylase and $\alpha$-glucosidase inhibition, and antioxidant activity of camel milk fermented with camel milk probiotic: A comparative study with fermented bovine milk. Food Chem. 239:588-597.

Ayyash, M. M., and N. P. Shah. 2011. Proteolysis of low-moisture Mozzarella cheese as affected by substitution of $\mathrm{NaCl}$ with $\mathrm{KCl}$. J. Dairy Sci. 94:3769-3777.

Benbrook, C. M. 2005. Elevating Antioxidant Levels in Food Through Organic Farming and Food Processing. The Organic Center, Washington, DC.

Brown, L., E. V. Pingitore, F. Mozzi, L. Saavedra, J. M. Villegas, and E. M. Hebert. 2017. Lactic acid bacteria as cell factories for the generation of bioactive peptides. Protein Pept. Lett. 24:146-155.

de Souza Oliveira, R. P., P. Perego, M. N. de Oliveira, and A. Converti. 2012a. Effect of inulin on the growth and metabolism of a probiotic strain of Lactobacillus rhamnosus in co-culture with Streptococcus thermophilus. Lebensm. Wiss. Technol. 47:358-363.

de Souza Oliveira, R. P., B. R. Torres, P. Perego, M. N. de Oliveira, and A. Converti. 2012b. Co-metabolic models of Streptococcus thermophilus in co-culture with Lactobacillus bulgaricus or Lactobacillus acidophilus. Biochem. Eng. J. 62:62-69.

Donkor, O. N., L. Stojanovska, P. Ginn, J. Ashton, and T. Vasiljevic 2012. Germinated grains - Sources of bioactive compounds. Food Chem. 135:950-959.

El-Salam, M. H. A., and S. El-Shibiny. 2013. Bioactive peptides of buffalo, camel, goat, sheep, mare, and yak milks and milk products. Food Rev. Int. 29:1-23

Elagamy, E. 2006. Camel milk. Pages 297-344 in Handbook of Milk of Non-Bovine Mammals. Y. W. Park and G. F. Haenlein, ed. Blackwell Publishing Professional, Ames, IA.
Elagamy, E., R. Ruppanner, A. Ismail, C. Champagne, and R. Assaf. 1996. Purification and characterization of lactoferrin, lactoperoxidase, lysozyme and immunoglobulins from camel's milk. Int. Dairy J. 6:129-145.

Elfahri, K. R., T. Vasiljevic, T. Yeager, and O. N. Donkor. 2016. Anticolon cancer and antioxidant activities of bovine skim milk fermented by selected Lactobacillus helveticus strains. J. Dairy Sci. 99:31-40.

FAO/WHO (Food and Agriculture Organization of the United Nations/World Health Organization). 2002. FAO/WHO Working Group Report on Drafting Guidelines for the Evaluation of Probiotics in Food. WHO, Geneva, Switzerland.

Fukuda, K. 2013. Camel milk. Pages $172-199$ in Milk and Dairy Products in Human Nutrition: Production, Composition and Health. Y. W. Park and F. H. George, ed. Wiley, Chichester, UK.

Gobbetti, M., F. Minervini, and C. G. Rizzello. 2004. Angiotensin I-converting-enzyme-inhibitory and antimicrobial bioactive peptides. Int. J. Dairy Technol. 57:173-188.

Gomes, J. J. L., A. M. Duarte, A. S. M. Batista, R. M. F. de Figueiredo, E. P. de Sousa, E. L. de Souza, and R. C. R. do Egypto. 2013. Physicochemical and sensory properties of fermented dairy beverages made with goat's milk, cow's milk and a mixture of the two milks. Lebensm. Wiss. Technol. 54:18-24.

Gomes da Cruz, A., F. C. A. Buriti, C. H. Batista de Souza, J. A. Fonseca Faria, and S. M. Isay Saad. 2009. Probiotic cheese: Health benefits, technological and stability aspects. Trends Food Sci. Technol. 20:344-354.

Habib, H. M., W. H. Ibrahim, R. Schneider-Stock, and H. M. Hassan. 2013. Camel milk lactoferrin reduces the proliferation of colorectal cancer cells and exerts antioxidant and DNA damage inhibitory activities. Food Chem. 141:148-152.

Hailu, Y., E. B. Hansen, E. Seifu, M. Eshetu, R. Ipsen, and S. Kappeler. 2016. Functional and technological properties of camel milk proteins: A review. J. Dairy Res. 83:422-429.

Harnedy, P. A., and R. J. FitzGerald. 2012. Bioactive peptides from marine processing waste and shellfish: A review. J. Funct. Foods $4: 6-24$

Khalesi, M., M. Salami, M. Moslehishad, J. Winterburn, and A. A. Moosavi-Movahedi. 2017. Biomolecular content of camel milk: A traditional superfood towards future healthcare industry. Trends Food Sci. Technol. 62:49-58.

Kim, Y. M., M. H. Wang, and H. I. Rhee. 2004. A novel $\alpha$-glucosidase inhibitor from pine bark. Carbohydr. Res. 339:715-717.

Korashy, H. M., Z. H. Maayah, A. R. Abd-Allah, A. O. El-Kadi, and A. A. Alhaider. 2012. Camel milk triggers apoptotic signaling pathways in human hepatoma HepG2 and breast cancer MCF7 cell lines through transcriptional mechanism. J. Biomed. Biotechnol. 2012:593195.

Kosikowski, F., and V. V. Mistry. 1977. Cheese and Fermented Milk Foods. Vol. 711. Edwards Bros., Ann Arbor, MI.

Layer, P., A. R. Zinsmeister, and E. P. DiMagno. 1986. Effects of decreasing intraluminal amylase activity on starch digestion and postprandial gastrointestinal function in humans. Gastroenterology $91: 41-48$.

Magjeed, N. A. 2005. Corrective effect of milk camel on some cancer biomarkers in blood of rats intoxicated with aflatoxin B1. J. Saudi Chem. Soc. 9:253-263.

Marco, M. L., D. Heeney, S. Binda, C. J. Cifelli, P. D. Cotter, B. Foligne, M. Gänzle, R. Kort, G. Pasin, and A. Pihlanto. 2017. Health benefits of fermented foods: Microbiota and beyond. Curr. Opin. Biotechnol. 44:94-102.

Marshall, V., and A. Tamime. 1997. Physiology and biochemistry of fermented milks. Pages 153-192 in Microbiology and Biochemistry of Cheese and Fermented Milk. B. A. Law, ed. Springer, London, UK.

McSweeney, P., and P. Fox. 1997. Chemical methods for the characterization of proteolysis in cheese during ripening. Lait 77:41-76.

Mihic, T., D. Rainkie, K. J. Wilby, and S. A. Pawluk. 2016. The therapeutic effects of camel milk: A systematic review of animal and human trials. J. Evid. Based Complement. Altern. Med. 21:NP110-NP126. 
Monteagudo-Mera, A., I. Caro, L. Rodríguez-Aparicio, J. Rúa, M. Ferrero, and M. García-Armesto. 2011. Characterization of certain bacterial strains for potential use as starter or probiotic cultures in dairy products. J. Food Prot. 74:1379-1386.

Moslehishad, M., M. R. Ehsani, M. Salami, S. Mirdamadi, H. Ezzatpanah, A. N. Naslaji, and A. A. Moosavi-Movahedi. 2013. The comparative assessment of ACE-inhibitory and antioxidant activities of peptide fractions obtained from fermented camel and bovine milk by Lactobacillus rhamnosus PTCC 1637. Int. Dairy J. $29: 82-87$.

Mostafa, T., A. El-Hamed, and H. Almetwaly. 2013. Effect of some nutritional treatments on productive performance of she-camels. J. Camel Pract. Res. 20:217-228.

Mymensingh, B. 2007. A comparative study on the quality of Dahi (yoghurt) prepared from cow, goat and buffalo milk. Int. J. Dairy Sci. 2:260-267.

Park, Y. W. 2009. Overview of bioactive components in milk and dairy products. Pages 1-12 in Bioactive Components in Milk and Dairy Products. Y. W. Park, ed. Wiley-Blackwell, Ames, IA.

Pessione, E., and S. Cirrincione. 2016. Bioactive molecules released in food by lactic acid bacteria: Encrypted peptides and biogenic amines. Front. Microbiol. 7:876.
Picot, L., S. Bordenave, S. Didelot, I. Fruitier-Arnaudin, F. Sannier, G. Thorkelsson, J. Bergé, F. Guérard, A. Chabeaud, and J. Piot. 2006. Antiproliferative activity of fish protein hydrolysates on human breast cancer cell lines. Process Biochem. 41:1217-1222.

Sah, B. N. P., T. Vasiljevic, S. McKechnie, and O. N. Donkor. 2014. Effect of probiotics on antioxidant and antimutagenic activities of crude peptide extract from yogurt. Food Chem. 156:264-270.

Shori, A. B. 2013. Antioxidant activity and viability of lactic acid bacteria in soybean-yogurt made from cow and camel milk. J. Taibah Univ. Sci. 7:202-208.

Shori, A. B. 2017. Camel milk and its fermented products as a source of potential probiotic strains and novel food cultures: A mini review. PharmaNutrition 5:84-88.

Shori, A. B., and A. S. Baba. 2014. Comparative antioxidant activity, proteolysis and in vitro $\alpha$-amylase and $\alpha$-glucosidase inhibition of Allium sativum-yogurts made from cow and camel milk. J. Saudi Chem. Soc. 18:456-463.

Tareb, R., M. Bernardeau, M. Gueguen, and J.-P. Vernoux. 2013. In vitro characterization of aggregation and adhesion properties of viable and heat-killed forms of two probiotic Lactobacillus strains and interaction with foodborne zoonotic bacteria, especially Campylobacter jejuni. J. Med. Microbiol. 62:637-649. 